\title{
Autogenous Closure of Oroantral Comunication: Different Surgical Approaches
}

\author{
Mohammad Adel Helmy* \\ BDS, Faculty of Dentistry, O6U, MDS Faculty of oral and dental medicine, Cairo University, Egypt
}

Submission: April 02, 2017; Published: April 07, 2017

*Corresponding author: Mohammad Adel Helmy, BDS, Faculty of Dentistry, O6U, MDS Faculty of oral and dental medicine, Cairo University, Egypt, Email:drmah84@gmail.com

\begin{abstract}
Oralantral communication is a pathological communication between the oral cavity and maxillary sinus which may be due to iatrogenic complications or from dental infections, radiation therapy or trauma, Therefore it should be treated carefully depending on the main cause of communication.
\end{abstract}

Keywords: Buccal flap; Palatal flap; Graft

\section{Introduction}

Oroantral communication (OAC) is a pathological pathway between the oral cavity and the maxillary sinus. Extraction of maxillary posterior teeth is the most common cause of OAC. Maxillary cysts, benign or malignant tumors and trauma can be other causes of OAC [1]. OACs must be sealed in order to prevent the escape of fluids, other mouth contents, and oral bacteria into the maxillary sinus. So the ideal treatment following creation of an OAC is to perform immediate surgical repair. Early treatment of OAC is very important to prevent formation of an oroantral fistula (OAF), to avoid development of chronic maxillary sinusitis, and is associated with a higher success rate [2].

Immediate plastic surgery of the oroantral fistula is effective in 95 percent, while a postponed surgery only in 67 percent [3]. In the light of recent studies and opinions, an oroantral fistula should be closed in 24 hours. After this period, in approximately half of the patients intensified inflammatory changes make it impossible to effectively conduct the treatment [3,4]. It occurs sometimes that the oroantral communication especially of a small size (up to $5 \mathrm{~mm}$ ) undergoes spontaneous healing provided that the sinus and the clot filling the alveolus are clean. However, this is not a method recommended by clinicians $[3,5,6]$. Considering current opinions, each oroantral communication should be treated surgically after previous diagnostics which excludes the presence of a foreign body and/or inflammatory changes of mucous membrane. An undiagnosed oroantral communication or treatment of an oroantral communication followed by complications results in chronic maxillary sinusitis. Its treatment involves removal of the oroantral fistula, surgery of the maxillary sinus and closure of the oroantral defect [5-7].

\section{Methodology}

\section{Autogenous Soft Tissue Flaps}

The most common surgical treatment of an OAC is the buccal advancement flap procedure designed by Rehrmann [8]. In this procedure a broad-based trapezoid mucoperiosteal flap is created and sutured over the defect. Its broad base assures adequate blood supply. Consequently, high success percentages (93\%) have been reported [9]. An alternative method for closure of OACs is the Môczáir flap [10]; this method involves a buccal muco-periosteal flap that is displaced 1 tooth width distally. The Môczáir flap is recommended for edentulous patients because the large denuded area, which is the result of the distal displacement of the buccal sliding flap, may give rise to periodontal disease in dentate patients. In addition, buccal sulcus depth is minimally influenced by advancement of the Môczáir flap in comparison with the Rehrmann method [11].

Full-thick-ness mucoperiosteal palatal flaps in various forms may especially be useful for closure of OACs larger than $10 \mathrm{~mm}$ [12]. A palatal flap, anteriorly based as described by Salins and Kishore [13] or posteriorly based, contains a large palatine vessel to ensure adequate blood flow. Itis less vulnerable to rupture than a buccal flap because of the thickness of the palatal 
mucosa. Further- more, the buccal sulcus depth remains intact. The buccal fat pad (BFP) is a lobulated mass of fatty tissue surrounded by a slight capsule, located inside the masticatory spaces $[14,15]$. The size of the BFP has proved to be constant among individuals, regardless of the fat distribution and body weight [16]. Blood supply to the BFP depends on branches of the superficial-temporal, maxillary, and facial arteries. Its use as a pedicled graft for reconstruction in oral surgery, including the closure of OACs, was first described by Egyedi [17] in 1977. One of the advantages of the BFP is the proximity of the BFP near the recipient area, permitting quick grafting. Tongue flaps can be created from the ventral, dorsal, or lateral part of the tongue [18]. In general, the location of the defect dictates the choice of tongue flap. Especially the lateral tongue is suitable for closure of OACs [19].

\section{Autogenous Bone Grafts}

Proctor [20] first suggested bone grafts harvested from the iliac crest for closure of large OACs in 1969. Nevertheless, bone grafting for closure of OACs has the disadvantage of requiring a second surgical procedure for bone harvesting. Watzak et al. [21] harvested retromolar bone for pressfitted closure of OACs in 4 patients. After placing the bone graft, soft tissue closure was realized by a Rehrmann buccal flap. No reopening of the sinus was observed. Chin bone for oroantral fistula closure was studied in 5 patients by Haas et al. [21]. In 3 patients a stable press-fit of the bone graft in the OAC was accomplished. In 2 patients additional plates and screws were used to obtain a rigid fixation of the graft. A Rehrmann flap was used in all patients for soft tissue closure. Wound dehiscence occurred in 1 patient, but the sinus remained unaffected. The use of a monocortical (chin) bone block for closure of an OAC is recommended for patients affected by maxillary atrophy requiring sinus augmentation before implant placement [22]. Peñarrocha-Diago et al. [23] used zygomatic bone as a bone graft for closure of an OAC in 1 patient. Subsequently 2 dental implants were placed. This technique offers the advantage of the proximity of the donor area to the recipient area, which minimizes surgical time and patient discomfort [23]. As in retromolar bone grafts, limited bone is obtainable from the zygomatic process. Furthermore, accidental sinus membrane perforation may occur [23].

\section{Discussion}

Generally, autogenous treatment of OACs is mostly safe, well tolerated by patients, has low costs, and with good bony and soft tissue healing with a low complication rate although it needs good anatomical and surgical skills for the desired results.

\section{References}

1. Thoma K, Pajarola GF, Grätz KW, Schmidlin PR (2006) Bioabsorbable root analogue for closure of oroantral communications after tooth extraction: a prospective case-cohort study. Oral Surg Oral Med Oral Pathol Oral Radiol Endod 101(5): 558-564.

2. Ehrl PA (1980) OAC, epicritical study of 175 patients, with special concern to the secondary operative closure. Int J Oral Surg 9(5): 351355 .
3. Visscher SH, van Roon MR, Sluiter WJ, van Minnen B, Bos RR (2011) Retrospective study on the treatment outcome of surgical closure of oroantral communications. J Oral Maxillofac Surg 69(12): 2956-2961.

4. Anavi Y, Gal G, Silfen R, Calderon S (2003) Palatal rotation-advancement flap for delayed repair of oroantral fistula: a retrospective evaluation of 63 cases. Oral Surg Oral Med Oral Pathol Oral Radiol Endod 96(5): 527-534.

5. Hernando J, Gallego L, Junquera L, Villarreal P (2010) Oroantral communications. A retrospective analysis. Med Oral Patol Oral Cir Bucal 15(3): e499-503.

6. Visscher SH, van Minnen B, Bos RR (2010) Closure of oroantral communications: a review of the literature. J Oral Maxillofac Surg 68(6): 1384-1391.

7. Akhlaghi F, Esmaeelinejad M, Safai P (2015) Etiologies and Treatments of Odontogenic Maxillary Sinusitis: A Systematic Review. Iran Red Crescent Med J 17(12): e25536.

8. Rehrmann VA (1936) Eine methode zur schliessung von kieferhohlen perforationen. Dtsch Zahnartl Wochenzeitschr 39: 1136.

9. Killey HC, Kay LW: Observations based on the surgical closure of 362 oro-antral fistulas. Int Surg 57:545, 1972.

10. Môczáir L (1930) Nuovo methodo operatiopela chisura delle fistole del seno mascellase di origina dentale. Stomatologiia (Roma) 28: 1087.

11. von Wowern N (1982) Closure of oroantral fistula with buccal flap: Rehrmann versus Moczar. Int J Oral Surg 11: 156-165.

12. Ehrl PA (1980) Oroantral communication. Epicritical study of 175 patients, with special concern to secondary operative closure. Int J Oral Surg 9(5): 351-358.

13. Salins PC, Kishore SK (1996) Anteriorly based palatal flap for closure of large oroantral fistula. Oral Surg Oral Med Oral Pathol Oral Radiol Endod 82: 253.

14. Martín-Granizo R, Naval L, Costas A, Goizueta C, Rodriguez F, et al. (1997) Use of buccal fat pad to repair intraoral defects: Review of 30 cases. Br J Oral Maxillofac Surg 35: 81-84.

15. Stuzin JM, Wagstrom L, Kawamoto HK, Baker TJ, Wolfe SA (1990) The anatomy and clinical applications of the buccal fat pad. Plast Reconstr Surg 85(1): 29-37.

16. Stuzin JM, Wagstrom L, Kawamoto HK, Baker TJ, Wolfe SA (1990) The anatomy and clinical applications of the buccal fat pad. Plast Reconstr Surg 85(1): 29-37.

17. Egyedi P (1977) Utilization of the buccal fat pad for closure of oroantral and/or oro-nasal communications. J Maxillofac Surg 5(4): 241-244.

18. Kim YK, Yeo HH, Kim SG (1998) Use of the tongue flap for intraoral reconstruction: A report of 16 cases. J Oral Maxillofac Surg 56: 716720 .

19. Buchbinder D, St Hilaire H (2003) Tongue flaps in maxillofacial surgery. Oral Maxillofac Surg Clin North Am 15(4): 475-486.

20. Proctor B (1969) Bone graft closure of large or persistent oromaxillary fistula. Laryngoscope 79(5): 822-826.

21. Watzak G, Tepper G, Zechner W, Monov G, Busenlechner D, et al. (2005) Bony press-fit closure of oro-antral fistulas: A technique for pre-sinus lift repair and secondary closure. J Oral Maxillofac Surg 63(9): 12881294.

22. Haas R, Watzak G, Baron M (2003) A preliminary study of monocortical bone grafts for oroantral fistula closure. Oral Surg Oral Med Oral Pathol Oral Radiol Endod 96: 263.

23. Peñarrocha-Diago M, Garcia B, Gomez D, Balaguer J (2007) Zygomatic bone graft for oral-antral communication closure and implant placement. J Oral Implantol 33(5): 305-309. 
(C) This work is licensed under Creative

BY DOI: $10.19080 / \mathrm{GJ} 0.2017 .06 .555689$

\section{Your next submission with Juniper Publishers} will reach you the below assets

- Quality Editorial service

- Swift Peer Review

- Reprints availability

- E-prints Service

- Manuscript Podcast for convenient understanding

- Global attainment for your research

- Manuscript accessibility in different formats

( Pdf, E-pub, Full Text, Audio)

- Unceasing customer service

Track the below URL for one-step submission https://juniperpublishers.com/online-submission.php 